\title{
Policy of Inclusive Education for Education for All in Indonesia
}

\author{
Asal Wahyuni Erlin Mulyadi•
}

\begin{abstract}
The purpose of this article is to discuss the basic and essential contents of the policy of inclusive education in Indonesia. Inclusive education is the recent worldwide agenda for educational reform toward the no-discrimination in education. Regardless of any condition and circumstances, it is guaranteed that every child has the right for education, as it is also clearly highlighted in the global program of Education for All (EFA). This paper is a content and analytic review on the national policy of inclusive education towards the education for all in Indonesia, i.e the Regulation of National Ministry of Education (PERMENDIKNAS) Number 70 Year 2009. Number of schools implementing the inclusive education policy has significantly increased, supported also by the province and district related regulations. However, the context of the policy of inclusive education as the major guideline for the policy implementation lead to various and even narrowed perspective on the concept of inclusion. Inclusive education is still discussed more in term of learners with disabilities only. Much progress has been made, yet it is still much left to be accomplished to achieve the fundamental and universal rights on education to all society.
\end{abstract}

\section{Keywords:}

education for all; inclusive education; public policy.

\section{Introduction}

Education is a fundamental right for all citizen protected under the national laws as well as international conventions. Regardless of any condition and circumstances, it is guaranteed that every child has the right for education, as it is also clearly highlighted in the global program of Education for All (EFA). The World Declaration on Education for All year 1990 stated that every person - child, youth and adult - shall be able to benefit from educational opportunities designed to meet their basic learning needs (UNESCO, 2009). It is also argued that education plays an important role in poverty alleviation and improve the human development index (EFACoordinationForum, 2014). In other word, education is a basic and essential elements for nations development.
The policy of inclusive education, the recent worldwide agenda for educational reform toward the no-discrimination in education, reflects the goals of Education for All (EFA). Inclusive education has been implemented by many countries worldwide as an endeavour to achieve no-discrimination in education (Poernomo, 2016). Inclusive education is a key strategy to achive Education for All (EFA) ensuring all learners for compulsory education. The above mentioned Education for All (EFA) goals (UNESCO, 2009) consist of first, to expand and improve comprehensive early childhood care and education especially for the most vulnerable and disadvantaged children; and second, to eansure all children have the access and complete free and good quality of compulsary primary education by 2015 . The

\footnotetext{
- Department of Public Administration FISIP Universitas Sebelas Maret Surakarta, Indonesia.

Email: aw.erlinmulyadi@gmail.com
} 
third is to ensure the learning needs through equitable access to appropriate learning and life-skills programs; and the forth is to achieve $50 \%$ improvement of adult literacy by 2015 as well as equitable access to basic and continuing education for all. The fifth goal is to eliminate gender disparities and achieve gender equality by 2015 , and the sixth is to improve all aspects of the quality of education including in literacy, numeracy and essential life skills.

In concordance with the international commitments, Indonesia declared the Indonesia toward Inclusive Education on August 2011. Up to year 2015, there are 60 regions (12 provinces and 48 district/cities) declared as the implementors province of inclusive education (Yusuf, 2016). The implementation of of iclusive education has been growing and developing rapidly in many parts of the country and UNESCO considers that the implementation of inclusive education for children with special needs in Indonesia pledges 65\% in 2015 (Poernomo, 2016). The national policy of inclusive education in Indonesia is the Regulation of National Ministry of Education Number 70 Year 2009 (called as Permendiknas 70/2009). This is in line with the Law 20/2003 on the National Education System mandating the concept of "compulsory basic education" for all citizen to support the Education for All (EFA) achievement. The government has decided to expand the compulsary education for the 12 years basic education program (OECD/AsianDevelopmentBank, 2015), which has been started from the 6 years program in 1984 and the 9 years in 1994. This compulsory program for all children for educational access in education shows the commitment of Indonesia to promote inclusive education and achieve Education for All (EFA).

This government commitment to implement inclusive education also reflects the constitutional right to all citizen to obtain education regardless their condition. It is illegal for schools to exclude children due to their disability condition (Powell, 2012). This also means as unjustifiable for any discrimination in education, and therefore exclusion of anyone from education is considered as a violation of law. A review on the context of policy of inclusive education and the basic perspective on inclusive education was found few. Inclusive education is still discussed more in term of learners with disabilities only. Moreover, other disadvantage and vurnerable learners in term of gender, religious, demographic, social and economic status including those with potential intellegent and special talents was found not yet accomodated while the goal highlighted the respect for the diversity and no discrimination for all learners. This paper will review the national policy of inclusive education in Indonesia called as the Regulation of National Ministry of Education (Permendiknas) Number 70 Year 2009, especifically in term of implicit contexts and primary provisions of the inclusive education. A recommendation for a reconceptualization of the concept of inclusive education as a part of national educational policy to achieve the goals of Education for All (EFA) is proposed.

\section{Methods}

A content and analytic review on the national policy of inclusive education towards the education for all in Indonesia is performed as a method in this literature review paper. A document analysis is increasingly recognized as a promising and innovative strategy for collecting and assessing data and are produced in and reflect specific social and historical circumstances (Segeren \& Kutsuruba, 2012). The Permendiknas 70/2009 is reviewed and assessed throughout. The articles related to the main context and provision of the policy are described and reflected. Data and any related descriptions about inclusive education and Education for All (EFA) from other resources are also applied to support the analysis and findings. 


\section{Results}

\section{Definitions of Inclusive Education}

Permendiknas 70/2009 signed by the Indonesia Ministry of Natonal Education dated October $5^{\text {th }} 2009$ regulates the aspects of: 1) the goals of inclusive education, 2) types of learners with abnormalities, 3) the acceptance of learners, 4) guarantee of the implementation of inclusive education by the government and local government, 5) the curriculum of inclusive education, 6) the learning process of inclusive education 7 ) the assesment of inclusive education. 8) the provision of special teacher by the government, 9) support fo the implementation, supervision, and monitoring on inclusive education, and 10) reward and punishment in the implementation of inclusive ducation. The mentioned policy, Permendiknas 70/2009, is about inclusive education for learners who have abnormalities and potential intelligence and/or special talents. Based on this, from the beginning it can be understood that this policy already indicate the existence of learner under the catagory of "abnormal". Interestingly, the Article 1 clearly define inclusive education as a system of education service providing opportunities for all learners who have abnormalities and potential intelligence and/or special talents to learn together with other general children. This further indicates about the two distinguished learners exist in this policy: "abnormal" and "general". In addition, learners who have abnormalities here are described as learners with physical, emotional, mental, and social abnormalities. It is further explained that learners who have such abnormalities include 1) blind;2) deaf;3) speech impaired;4) mentally disabled; 5) maladjusted; 6) tuna barrel; 7) learning difficulties; 8) sluggish learning; 9) autism; 10) motoric disruption; 11) become victims of drug abuse, drugs, and other addictive substances; 12 ) other abnormalities; and 13) tunaganda.
It is unarguably shows that the policy of inclusive education of Indonesia with Permendiknas 70/2009 has already indicated the specialization for accommodate learners with special needs in the sense of person with disabilities which is also labelled as having abnormalities. The policy does not show the consideraton on other possible excluded or marginalized / vulnarable children under the circumstances of social economic status, gender, religion, ethnicity, etc. There are two main goals of inclusive education stated under Article 2. The first goal is providing wide opportunity to all learners who have abnormalities and potential intelligence and/ or special talents to obtain education that suits their needs and abilities. The second goal is realizing the implementation of education that values diversity and is not discriminatory for all learners who have abnormalities and potential intelligence and/or special talents. Again, while highlighting the value of diversity and no discrimination, this policy instead only focus for learners with disabilities and segregate abnormal and general catagories of learners.

Unfortunately, this is also supported by the Indonesian Law number 20 year 2003 about the National Education System. Under this policy, especially on Article 32, Indonesia implemented special education and special service education. Special education is education for all learners who have difficulties in the learning process due to their phisics, mental, social abnormalities and/ or have potential intellegence and special talents. Special servise education is education intended for all learners in the isolated area, indigenous people and/or experienced the natural or social disasters and with low economic status. It can be understood that while moving to inclusive education, the implementation of the policy is still focus only for learners with disabilities as well as the two other catagories, special education and special servidce education, which is apart from the regular education. 
Similarly, the content of regional policy also accommodates the perspective view that the implementation of inclusive education means to accommodate students with disabilities. An example of the district government regulation on Inclusive reulation is the Yogyakarta Municipal Regulation Number 47 Year 2008. Another example is the Regulation of the Governor of Aceh Number 92 year 2012 on the implementation of inclusive education in line with the Qonun of Aceh Governor Number 5 year 2008 on the implementation of education. The Regent of Aceh Besar also issued the Qonun of Aceh Besar Regent Number 6 year 2010 on the management of the implementation of inclusive education. All of those regulations are understood as accomodating person with disabilities to be included in a regular schools together with regular students to perform an inclusive education. Its implementation to take into account to those with intellectual disabilities however remains left unexamined.

As mentioned above, Permendiknas $70 / 2009$ is also about learners who have potential intelligence and/or special talents. Nonetheless, out of the 15 Articles on the policy, there is none mentioning the catagories for such learners who have potential intelligence and/or special talents. This lack of coverage on essential points of the policy can be claimed that Permendiknas 70/2009 is an incomplete policy. All the articles on the policy are about inclusive education for learners with special needs a.k.a learners with abnormalities or disabilities. In fact, the comprehensive basic value of inclusiveness is still encountered by misunderstandings among others that inclusion is the same as difable which then accumulated in general understanding that inclusive education is education accommodating people with disability only. In some newspapers for example, it is often found even in a large headline written like: "inclusive students have difficulty understanding charts and drawings", "schools should receive inclusive students", "inclusive students are not privileged", and the like. It shows the missused due to the missunderstanding of the world inclusive or inclusion. In other words, it supports the misslead of the comprehensive basic value of inclusive education as education for learner with special needs in term of person with disabilities only.

\section{Primary Provisions}

The Indonesian education system concsist of four level of education i.e early childhood, basic, secondary, and higher education (see Table 1). In related to this, Article 4 of the Permendiknas 70/2009 stipulates the district/ municipal governments to appoint at least one primary school and one junior secondary school as well as one senior or vocational secondary school (in the level of secondary education) in each sub-district to implement inclusive education. It was also explained that other schools which are not appointed by the government to implement inclusive education are allowed to accept learners who have abnormalities and potential intelligence and/ or special talents.

The appointed schools to implement the inclusive education, under Article 5 of the Permendiknas 70/2009 are required to consider their resources, and Article 6 stated that the government have to guarantee the availability of the resources for inclusive education. Article 5 of the policy also stated that the allocation to accept learners who have abnormalities and potential intelligence and/ or special talents is at least one seat in each school year. In more details, Article 10 and Article 11 stated that the district/municipal government has to provide at least one special teacher and give professional support to the schools implementing inclusive education. This regulation can be a solution for both appointed schools and unappointed schools implementing inclusive education but claiming the lack of resources as the major reasons 
Table1.

The Feature of Indonesian Education System

\begin{tabular}{|c|c|c|c|}
\hline Level & Track & School & $\begin{array}{c}\text { Age of } \\
\text { Schooling }\end{array}$ \\
\hline \multirow{4}{*}{ Basic Education } & \multirow{2}{*}{ Formal } & $\begin{array}{ll}\text { 1. } & \text { Primary School } \\
\text { 2. } & \text { Islamic Primary School }\end{array}$ & $7-12$ years old \\
\hline & & $\begin{array}{l}\text { 1. Junior Secondary School } \\
\text { 2. Islamic Junior Secondary School }\end{array}$ & 13-15 years old \\
\hline & & Package A & 7-12 years old \\
\hline & Non Formal & Package B & $13-15$ years old \\
\hline \multirow[t]{2}{*}{ Secondary Education } & Formal & $\begin{array}{l}\text { 1. Senior Secondary School } \\
\text { 2. Vocational Secondary School } \\
\text { 3. Islamic Senior Secondary School }\end{array}$ & $16-18$ years old \\
\hline & Non Formal & Package C & \\
\hline Higher Education & & $\begin{array}{l}\text { Universities/Institute offers the following programs: } \\
\text { 1. Non degree program: } \\
\text { Diploma I } \\
\text { Diploma II } \\
\text { Diploma III } \\
\text { Diploma IV } \\
\text { 2. Degree program: } \\
\text { Strata I (Bachelor) } \\
\text { Strata II (Master) } \\
\text { Strata III (Doctorate) } \\
\text { 3. Professional program equals to master and doctorate }\end{array}$ & 19-29 years old \\
\hline
\end{tabular}

to the unsuccesfull of its implementation. Moreover, under Article 14 is regulated that the educational unit implementing inclusve education violating the provisions as regulated in this policy shall be given administrative sanctions in accordance with the provisions and laws.

Unfortunately, despite the number of schools implementing inclusive education is reported increase year by year, the primary provision of Permendiknas has not fully implemented. For example, the primary provision on this policy to have a minimum of one school implementing inclusive education (especially for junior and senior secondary school) has not yet fully performed. In Yogyakarta city, the first and reference city center implementing inclusive education, it was found that there are some districts out of the 14 districts which do not have a junior and/or senior secondary school appointed to implement inclusive education (see Table 2). There is no report found about the schools that are not appointed as inclusive schools yet accepting learners who have abnormalities and potential intelligence and/or special talents. In addition, the Indonesia Social Economic Survey (2012) reported that only $4.06 \%$ and $2.04 \%$ of elementary and secondary schools implement inclusive education repsctively. There is also no report found about the administrative sanctions given to any schools in related to policy violation on inclusive education.

Another provision in this policy, Article $5 c$, states that if within the time specified, the allocation of learners as referred above cannot be fulfilled, the educational unit may accept normal learners. The mention of "normal learners" in this policy again indicates a label that distinguishes the presence of "abnormal" learners who in this case refer to learners who have abnormalities and potential intelligence and/or special talents. It means that in this policy, with the aim of raising the nodiscrimination for all in education, instead still indeed dealing with the issue of segregation between normal and abnormal students.

In addition, as a part of educational education system in Indonesia, there is also a regulation on the system of special education 
Table 2.

Inclusive schools in Yogyakarta City

\begin{tabular}{lccc}
\hline & \multicolumn{3}{c}{ Number of Inclusive School } \\
\cline { 2 - 4 } \multicolumn{1}{c}{ Subdistrict } & $\begin{array}{c}\text { Primary } \\
\text { School }\end{array}$ & $\begin{array}{c}\text { Junior } \\
\text { Secondary } \\
\text { School }\end{array}$ & $\begin{array}{c}\text { Senior/ } \\
\text { Vocational } \\
\text { Secondary } \\
\text { School }\end{array}$ \\
\hline Mantrijeron & 2 & 0 & 0 \\
Kraton & 1 & 0 & 0 \\
Mergangsan & 4 & 1 & 1 \\
Umbulharjo & 8 & 2 & 2 \\
Kotagede & 1 & 1 & 2 \\
Gondokusuman & 4 & 0 & 4 \\
Danurejan & 1 & 2 & 0 \\
Pakualaman & 0 & 1 & 0 \\
Gondomanan & 0 & 0 & 1 \\
Ngampilan & 1 & 0 & 0 \\
Wirobrajan & 1 & 0 & 4 \\
Gedongtengen & 0 & 1 & 0 \\
Jetis & 2 & 1 & 0 \\
Tegalrejo & 3 & 0 & 1 \\
\hline
\end{tabular}

Source: data modified from the appendix of the decree of education authorities of Yogyakarta City Number 188/376 Year 2016.

which proved further about the segregation system implemented in Indonesia. This special education system for special schools include all level of compulsary education: kinderganten, primary, junior secondary, and senior secondary schools. These schools are under the responsibility of Directorate of Special Education in the Ministry of National Education of Indonesia. The existence of special education department under the ministry of education further indicate about the segregation applied in the educational system in Indonesia. Thus, although it has moved to the latest approach of inclusive education to eliminate discrimination and achieve education for all, Indonesia is also still implementing a segregation system. The types of the special schools (called as Sekolah Luar Biasa/SLB) provided are: 1) SLB A: for visual impairment; 2) SLB B: for hearing impairment; 3) SLB C: for mild intellectual disability; 4) SLB C1:for moderate intellectual disability; 5) SLB D: for physical impairment; 6) SLB E: for emotional-social behaviour difficulties; 7) SLB G: for multiple disabilities; and 8) SLB M: for autistic children.

The concept of inclusive education is understood as education for persons with disabilities by the majority of the community, including even street level bureaucrats in schools (such as teachers and principals). Furthermore, as explained above, in some media reports, the mention of learners with special needs is often synonymous and interchangeably with the term of inclusive students. Actually, this narrowed perspective is possible to be understood as the Permendiknas 70/2009 already stated clearly that inclusive education is education for learners who have abnormalities and have the potential of intelligence and / or special talents. It means that the policy of inclusive education in Indonesia through the mentioned Permendiknas is mostly intended to accommodate education for all for students with disabilities. In other words, in this policy although mentions about special talents and other disadvantaged group such as gender, ethnicity, social economic status, child victims of drug abuse, drugs, and other addictive substances, but in general inclusive education is missunderstood as education to accommodate people with disabilities only. Moreover, with the exsistences of the special schools for students with special needs, despite the debate emerged, indicate that the segregation system in Indonesia is also implemented.

\section{Discussion}

\section{Narrowed Perspectives on Inclusive Education}

Inclusive education is argued as a contentious terminology which possible to lead to various misconception and confusion. Governments worldwide have various different meanings to the concept of inclusive education. Even within a country, such understanding may vary from province to province, district to district and even school to school 
(International, 2009). In Indonesia, under the Permendiknas 70/2009 inclusive education is found to be viewed as accomodating childrens with diabilities only. This shows a narrowed perspectives on and even a missconception of the basic value of inclusive education. In addition, the move towards inclusive education is still shadowed by segregation and discrimination issues. This finding is similar to other study (Handayani \& Rahadian, 2013) reported that various regulation in Indonesia including the Permendiknas 70/2009 are still applied the discrimination in edutation which is in contrary to the nature and basic principles of inclusive education. Interestingly, such issues of discrimination in education was also found on the primary regulation on education in Indonesia. The Law 20/2003 on the National Education System also cover the space for special education for students with special needs and special service education for those in isolated area, indigenous people and/or experienced the natural or social disasters and with low economic status. It is also highlighted in the findings of the other study (Handayani \& Rahadian, 2013) that various regulations in Indonesia have not yet accommodate the right concept of inclusive education as a development approach in the field of education. Similarly, this concerns indicates the educational needs of minority and discriminated groups in a vision of inclusive education that require specific policy efforts in order to disrupt deeply rooted segregative traditions (Rambla \& Langthaler, 2016).

Having an accurate understanding of the policy context is important for its implementation. Developing a local understandings of the complex concepts of "education", "all", and "inclusion" is crtical to the development of appropriate and sustainable policies on teaching and learning (Miles \& Singal, 2010). It is also reminded that in the discussion on inclusive education has to move towards the fundamental aspect which is the perspectives on what it is and not only focus on the issues of resources and its curriculum (Ro'fah, 2016). It is also globally suggested that describing a clear understanding the meaning of inclusive education is helpful to set benchmarks for progress towards inclusion (International, 2009).

It is recognized worldwide that inclusive education is still thought of in some countries as an approach to serving children with disabilities within general educational settings (UNESCO, 2009). As a consequence, the narrowed perspectives on inclusive education as discussed above is understandable and become an unfinished discussion. Beside the context of the mentioned policy, initially the development of inclusive education focuses on person with disabilities and learning difficulties (Ainscow, Booth, \& Dyson, 2006). Moreover, a brief report on inclusive education in Vienna suggested that inclusive education is generally conceived of as special needs education (and most often only as education for children with disabilities) with little sensitivity for equity issues in a broader sense (Rambla \& Langthaler, 2016). Referring to some scholars opinion, the focus of inclusive education should not be restricted only to leraners with special needs but extended to broader approach such as ability, gender, race, ethnicity, religion, language, sexuality, social status and economics (Dagnew, 2013). Other study also identified the consideration of a broader concept of inclusive education concerned with identifying and removing barriers to learning participation and achievement for all students (Kurawa, 2010). UNESCO also reported that inclusive education now is internationally viewed in more broader concept as a reform supporting and welcoming diversity amongst all learners (UNESCO, 2009).

In summary, while highly acknowledge the significant increase on achieving education for all through inclusive education, it is needed to spread out the nature and basic value of inclusive education. It was argued that 
Table 3.

Definition of Inclusion

\begin{tabular}{|c|c|}
\hline Inclusion is: & Inclusion involves \\
\hline $\begin{array}{l}\square \text { Recognition of the right to education and its } \\
\text { provision in non-discriminatory ways } \\
\square \text { A common vision which covers all people } \\
\square \text { A belief that schools and other places of learning } \\
\text { have a responsibility to educate all children (and } \\
\text { adults) in line with human roght principles } \\
\square \text { A continous process of adressing and responding } \\
\text { to the diversity of needs of all learners-regardless } \\
\text { of factors such as disability, gender, age, ethnicity, } \\
\text { languange, HIV status, geographical location and } \\
\text { sexuality-regognising that all people can learn }\end{array}$ & $\begin{array}{l}\square \text { Providing appropriate responses to the broad spectrum } \\
\text { of larning needs in formal and other education settings } \\
\square \text { A particular emphasis on those groups of learners who } \\
\text { may be at risk of marginalisation, exclusion or under } \\
\text { achievement } \\
\square \text { Identification and removal of attitudinal environtmental } \\
\text { and institutional barriers to participation and learning } \\
\square \text { Modification and changes in strategies and plans and in } \\
\text { contents and approaches to learning } \\
\square \text { Enabling teachers and learners to see diversity as an asset } \\
\text { rather than a problem }\end{array}$ \\
\hline
\end{tabular}

Source: Adopted from the UNESCO's Guidelines for inclusion: Ensuring Access to Education for All (Sightsavers, 2011)

focusing on a single factors, i.e person with disabilities, has the potential to lead to faulty understanding and therefore it is important to put inclusive education under the fundamental human rights (Dagnew, 2013). In the future, it is expected that the wider perspective and good understanding on inclusive education will bring more achivement for education for all. Inclusion is not about disability but it is more about social justice (Sapon-Shevin, 2003). Table 3 shows the definition of inclusion to help deeper understanding the fundamental meaning of inclusion. Inclusion is about non-discriminatory for all regardles their circumstances such as disability, gender, age, ethnicity, languange, HIV status, geographical location, sexuality-regognising, and the like. While also recognising and emphasising the vurnerable and marginalised groups of learners, inclusive education accommodate all learners and not only person with disabilities only.

\section{EFA Achievement through Inclusive Education}

The Human Development Index for Indonesia shows a considerable improvement year by year (see Table 5). In year 2011 Indonesia is in the position of 124 out of 187 countries with $\mathrm{HDI}=0.617$. In year 2012 Indonesia reached the position of medium human development (with HDI= 0.64), however it is under the neighbourhood countries such as Thailand, The Phillipines, and Malaysia. In year 2013, the position of Indonesia is in the rank of 121 out of 185 countries, and in year 2014 increase to the rank of 110 out of 188 countries with HDI $=0.686$ (UNDP, 2016). This significant achievement showed the successful of education program in Indonesia.

In addition, the number of schools implementing inclusive education shows a high increase amost for times during the last 10 years. It was reported that the initial pilot project for inclusive education in 2007, the number of the schools implementing inculsive education in the level of primary, elementary, junior, and senior high schools is 796 schools (Direktorat Pembinaan SLB, 2007). In 2017, the Indonesia Ministry of Ecucation and Culture reported that the number of elementary, junior, and highschools impelementing inclusive education reached 31.724 schools (Kemdikbud, 2017). In Yogyakarta city, in 2008 the number of inclusive schools was 14 schools and increase almost 500\% (63 schools) in 2016 (based on the appendix of the Decree of Education Authorities of Yogyakarta City number 188/376 year 2016). It indicates that Indonesia has been shifting towards more inclusive education that provides quality education for all children including children with disabilities and to 
Table 4.

Indonesia Human Developments Index Indonesia year 1990 - 2015

\begin{tabular}{cccccc}
\hline Year & $\begin{array}{c}\text { Life expectancy at } \\
\text { birth }\end{array}$ & $\begin{array}{c}\text { Expected years of } \\
\text { schooling }\end{array}$ & $\begin{array}{c}\text { Mean years of } \\
\text { schooling }\end{array}$ & $\begin{array}{c}\text { GNI per capita } \\
\text { (2011 PPP\$) }\end{array}$ & HDI Value \\
\hline 1990 & 63.3 & 10.1 & 3.3 & 4.270 & 0.528 \\
1995 & 65.0 & 10.1 & 4.2 & 5.844 & 0,564 \\
2000 & 66.3 & 10.6 & 6.7 & 5.243 & 0,604 \\
2005 & 67.2 & 10.9 & 7.4 & 6.495 & 0,632 \\
2010 & 68.1 & 12.3 & 7.4 & 8.234 & 0,662 \\
2011 & 68.3 & 12.6 & 7.5 & 8.607 & 0.669 \\
2012 & 68.5 & 12.9 & 7.6 & 9.017 & 0.677 \\
2013 & 68.7 & 12.9 & 7.8 & 9.392 & 0.682 \\
2014 & 68.9 & 12.9 & 7.9 & 9.703 & 0.686 \\
2015 & 69.1 & 12.9 & 7.9 & 10.053 & 0,689 \\
\hline
\end{tabular}

Source: (UNDP, 2016)

Figure 1.

The Decrease of Percentage and Number Adult Illiteracy, 2005-2012

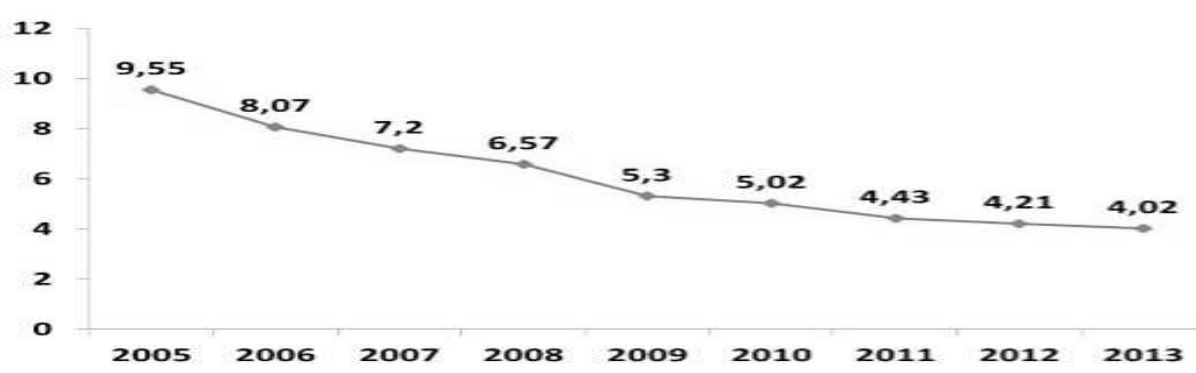

Source: (EFACoordinationForum, 2014)

decrease the number of students in special schools (OECD/Asian Development Bank, 2015). Unfortunately, it was also reported that amongst the large number of inclusive schools, in fact some are not ready to implement the inclusive education due to some reasons such as the lack of human resources and infrstructures (Kemendikbud, 2016). In 2015, the number of $A B K$ was reported still reached about 1,6 millions and only about 229 learners $(18 \%)$ accessed the inclusive schools and 115 attended SLB (Kemdikbud, 2017).

Furthermore, it was reported that the number of adult illeteracy in Indonesia for the period of 2005-2013 shows a significant decrease (see Fig. 1). However, the literacy rate in Indonesia is still quite high despite the significant achievement of the basic program for all (Manan, 2015). Although Indonesia has made remarkable progress in improving access to basic education, $6.7 \%$ of primary school age children and $23.4 \%$ of junior secondary school age children are not enrolled in schools . School participation rate shows an increase in 10 years (2003-2013), nontheless, as can be seen in Table 4, the school participation rate for those on the group age of 16-18 years old only reached $63.27 \%$. The number of drop out student before reaching high school reached 3.1 million per year, since only 2.2 millions student will graduate from high school out of 5.3 million entered the first grade (Baswedan, 2012). Regional disparities between and within provinces were also reported to be highly considered. The net enrolment rate ranges from $94.7 \%$ in Bali to $83.1 \%$ in West Papua at primary school and from $94.7 \%$ in the Special Capital Region (DKI) of Jakarta to $31.6 \%$ in Papua fo 
secondary school.

Table 4.

Participation in Formal Education

\begin{tabular}{lcc}
\hline Education Indicators & $\mathbf{2 0 0 3}$ & $\mathbf{2 0 1 3}$ \\
\hline Partcipation in Formal Education & $\mathbf{\%}$ & $\mathbf{\%}$ \\
\hline School Participation rate & & \\
$\quad$ 7-12 years old & 96.42 & 98.29 \\
13-15 years old & 81.01 & 90.48 \\
16-18 years old & 50.97 & 63.27 \\
19-24 years old & 11.71 & 19.88 \\
\hline
\end{tabular}

Source: Adopted from BPS-Badan Pusat Statistik, 2014 (EFACoordinationForum, 2014)

Several barriers reported in some study findings on the implemetation of inclusive education in Indonesia include the lack of trained teachers and their understanding (Yusuf, 2016), the lack of infrastructures, human resources, and support from the society (Handayani \& Rahadian, 2013) as well as lack of information and discriminatory attitude towards person with disabilities (Poernomo, 2016). Even in New Zealand, a study findings stated that the small number and low level of school counselors at the primary school level (only one counselor for every three schools) was considered ineffective services (Mundia, 2009). With the various successes achieved, it can be said that the implementation of inclusive education policy in Indonesia has supported the achievement of EFA objectives although it is not yet maximal. Although there has been significant progress in achieving the right to education, the Indonesian government remains facing the difficulty to provide fulfill the right to all highly diverse citizens in Indonesia (Manan, 2015).

There are still many aspects that need to be prepared, maintained, and also improved as this is ofcourse not an easy and fast task. Examples of good education is available and provided in special schools in Indonesia and some regions are working to develop more inclusive approaches to education across all stages but there is still much to do. Enrolment of students with additional support needs in senior secondary schools remains very low (OECD/AsianDevelopmentBank, 2015). It is also needed to reform educational policy in Indonesia to meet inclusive education goal (Handayani \& Rahadian, 2013) and support the achievement of the program of education for all. It is also important also to notice the immense and diverse education system in Indonesia. There are two ministries that are responsible for managing the system of education, i.e the Ministry od Education and Culture and Ministry of Religious Affair covering $84 \%$ and $16 \%$ of schools respectively (OECD/AsianDevelopmentBank, 2015). Given this fact, a multi-key educational providers coordination also become another source of concerns in achieving the goals of education for all.

\section{Conclusion}

The implementation of inclusive education is unquestionably important to achive EFA. It was found that the number of the school implementing the inclusive education policy has significantly increased, supported also by the province and district related regulations. However, the context of the policy of inclusive education as the major guideline for the policy implementation lead to various and even narrowed perspective on the concept of inclusion. Further discussion is still on board up to know since the essential as well as the implementation of inclusive education also raise some pro and contra's issues. Amongst the issues include the possibilities to accommodate all learners with various diversities and needs, the availability of infrastructures and human resources, and also the acceptances of all stakeholders and society for the implementation of inclusive education to achive a no discrimination in any circumstances of the learners in education for all.

It is important to be highlighted that much progress has been made, yet it is still much left 
to be accomplished to achieve the fundamental and universal rights on education to all society. Nationally the target of educational policy through all the various implemented program was reported shows a significant achiements, nonetheless disparities among provinces and districts remains as unresolved issues.

To implement an ideal inclusive education need a long process, moreover external factor such as geographical landscape/position of Indosia as an archipelago country also consider as a big barrier. Although it has been academically discussed, a proper and holistic understanding on inclusive education remains important to note. A reconceptualization of inclusive education as a guarantee of quality and access may improve the implementation of inclusive education and thus EFA goals will be greatly achieved.

\section{References}

Ainscow, M., Booth, T., \& Dyson, A. (2006). Inclusions and the standards agenda: negotiating policy pressures in England. International Journal of Inclusive Education, 10(4), 295-308.

Baswedan, A. (2012). Higher education as an instrument for structural changes in Indonesia. http://www.usindo.org/resources/highereducation-as-an-instrument-for-structuralchange-in-indonesia.

Dagnew, A. (2013). Factors affecting the implementation of inclusive education in primary scgools of Bahir Dar Town Administration. Education Research Journal, 3(3), 59-67.

EFACoordinationForum. (2014). Education for All 2015 National Review Report: Indonesia. Jakarta: Education for All Coordination Forum Ministry of Education and Culture. Handayani, T., \& Rahadian, A. (2013). Peraturan perundangan dan implementasi pendidikan inklusif. Masyarakat Indonesia, 39(1), 27-48.

IndonesiaMinistryofNationalEducation. (2008). Country Report: Indonesia Indonesian Public
Policies on Inclusive Education. Jakarta.

International, I. (2009). Better Education for All: When We're Included Too.

Kemdikbud. (2017, February 01). Sekolah inklusi dan pembangunan SLB dukung pendidikan inklusi. Retrieved September 04, 2017, from www.kemdikbud.go.id: https://www. kemdikbud.go.id/main/blog/2017/02/ sekolah-inklusi-dan-pembangunan-slbdukung-pendidikan-inklusi

Kemendikbud. (2016). Gambaran sekolah inklusif di Indonesia: Tinjauan Sekolah Menengah Pertama. Jakarta: Pusat Data dan Statistik Pendidikan dan Kebudayaan Kementrian Pendidikan dan Kebudayaan.

Kurawa, G. (2010). The views of students and practitioners of how to include all children in learning and regular classrooms. Procedia Social and Behavioral Sciemces, 1550-1555.

Manan, M. (2015). The implementation of the right to education in Indonesia. Indonesia Law Review, 51-68.

Miles, S., \& Singal, N. (2010). The education for all and inclusive education debate : Conflict, contradiction or opportunity? International Journal of Inclusive Education, 1-20.

Mundia, L. (2009). Implementation of inclusive education in Brunei Darussalam: Review of possible implications for school counselors. Electronic Journal for Inclusive Education, 2(4), 1-30.

OECD/AsianDevelopmentBank. (2015). Education in Indonesia: Rising to the Challenge. Paris: OECD Publisher.

Poernomo, B. (2016). The Implementation of Inclusive Education in Indonesia: Current Problems and. American International Journal of Social Science, 144-150.

Powell, D. (2012). A Review of Inclusive Education in New Zealand. Electronic Journal for Inclusive Education, 2(10), 1-17.

Rambla, X., \& Langthaler, M. (2016). The SDGs and inclusive education for all: From special education to addressing social inequalities. Vienna: Austrian Foundation 
for Development Research.

Ro'fah. (2016). Inclusion is ... Jurnal Difabel, 3(3), xi-xii.

Sapon-Shevin, M. (2003). Inclusion: A matter of social justice: How can we create schools that will help students thrive in a diverse society? Education Leadership, 61(2), 25-28.

Segeren, A., \& Kutsuruba, B. (2012). Twenty years and counting: An examination of the development of equity and inclusive education in Otario (1990-2010). Canadian Journal of Educational Administration and Policy, September(136), 1-38.

Sightsavers. (2011, July). Policy papers:
Making inclusive education a reality. Retrieved February 14, 2017, from www. sightsavers.org: https;//www.sightsavers. org/reports/2011/07/making-inclusiveeducation-reality/

UNDP. (2016). Human Development Report 2016: Indonesia. New York: UNDP.

UNESCO. (2009). Policy Guidelines on Inclusion in Education. . Paris: UNESCO (2009) Policy The United Nations Educational, Scientific and Cultural Organization.

Yusuf, M. (2016). Refleksi iImplementasi pendidikan inklusif di Indonesia. Jurnal Difabel, 3(3), 67-80. 